\title{
A casa letrada: desejo de posse, desconfiança e escrita de Paulo Honório em São Bernardo
}

\author{
Marcel Vejmelka*
}

Desejo de posse, desconfiança e escrita - estes elementos representam três aspectos fundamentais tanto do protagonista Paulo Honório quanto da composição do romance São Bernardo, de Graciliano Ramos. Focalizando a importância do contexto da escrita, no seu desdobramento encenado pelo texto de São Bernardo enquanto contexto da escrita do narrador e autor, estas três linhas se entrelaçam e se combinam de variadas formas, sintetizadas na metáfora da "cidade letrada". Com este conceito analítico e simbólico, Ángel Rama (cf. 200o, p. 9) descreve os imbricamentos da cidade colonial com o domínio da cultura letrada no processo de formação social e cultural da América Latina. Rama enfoca os processos da formação das literaturas latino-americanas e da própria elite letrada. Esta configuração se complica dentro do domínio literário, onde se sobrepõem a formação dos respectivos sistemas literários nacionais durante o século XIX e a formação de sistemas literários regionais. No contexto dado, interessa particularmente o "subsistema literário do nordeste brasileiro" (cf. CANDIDO, 20oo, p. 23-37). A escrita enquanto problema e dificuldade, necessidade e possibilidade, representa as dimensões centrais na constituição e construção do romance de Graciliano Ramos, como mostra Anatol Rosenfeld:

É interessante notar que Paulo Honório, o senhor de terras, que escreve sua história após o suicídio da mulher, atribui seus desentendimentos com Madalena à forma diferente dela se exprimir. [...] Isto não é apenas uma polêmica contra a cultura retórica da região costeira, da qual sua mulher como professora participava, e contra uma literatura toda bombástica, odiada por Graciliano, mas também indica a distância cultural entre a cidade e o sertão (RosENFELD, 1994, p. 145-146).

Rosenfeld situa a textualidade do romance dentro da problemática relação de seu autor com os princípios do regionalismo e do modernismo. Além disso, denomina o conflito central que orienta a escrita de São Bernardo, apreendido e analisado no interior dos processos de significação e narração do texto literário. É o

\footnotetext{
Doutor em estudos latino-americanos/brasileiros pela Universidade Livre de Berlim e professor do departamento de Espanhol e Português da Universidade Johannes Gutenberg de Mainz, campus de Germersheim, Alemanha. E-mail: vejmelka@uni-mainz.de.
} 
mesmo conflito que rege a problemática do regionalismo no contexto brasileiro e latino-americano, onde a obra de Graciliano Ramos figura em lugar destacado. Uma problemática estreitamente ligada com o conflito entre meio "inculto" e a cultura letrada, analisado por Rama na sua concepção de "transculturação narrativa":

A este conflito os regionalistas reagem, fundamentalmente, procurando que não se produza a ruptura da sociedade nacional, que está vivendo uma transformação díspar. A solução intermédia é a mais comum: aproveitar as contribuições da modernidade, revisar à luz delas os conteúdos culturais regionais e, com essas e aquelas fontes, compor um híbrido capaz de continuar transmitindo a herança recebida. Será uma herança renovada, que entretanto ainda pode identificar-se com o seu passado (RAMA, 2004, p. 29). ${ }^{1}$

Estas coordenadas constituem o espaço analítico dentro do qual São Bernardo ocupa um lugar singular, pelas suas caraterísticas específicas de construção e escrita literária.

\section{O desejo de posse}

No contexto da modernização contraditória do nordeste brasileiro um eixo central para a construção de São Bernardo é a propriedade enquanto posse material, poder econômico e controle individual. O afã de propriedade constitui o filo condutor da vida do protagonista e narrador Paulo Honório. Num ensaio pioneiro, Otto Maria Carpeaux aponta para a importância fundamental do desejo de posse, e o liga a uma "técnica do sonho" na construção da narrativa em volta de Paulo Honório:

O extremo egoísmo do sonho engendra o motivo principal do romancista: cobiça de propriedade. Propriedade de terra, de mulher, em São Bernardo; aqui e em Angústia, a forma extrema desta cobiça, o ciúme. Por isso, nos romances de Graciliano Ramos, esses afetos ultrapassam toda medida; sugerem, ao lado dos afetos análogos na vida real, a impressão de sentimentos patológicos (CARPEAUX, 1977, p. 31).

Em outro estudo clássico, Antonio Candido retoma esta análise e interpreta São Bernardo como "verdadeira patogênese do sentimento de propriedade", intensificando a análise crítica do personagem-narrador enquanto instância controladora do discurso narrativo e de todas as personagens. A instância narrativa aparece, portanto, regida pelo mesmo afã de posse que o protagonista:

\footnotetext{
"A ese conflicto que responden los regionalistas, fundamentalmente procurando que no se produzca la ruptura de la sociedad nacional, la cual está viviendo una dispareja transformación. La solución intermedia es la más común: echar mano de las aportaciones de la modernidad, revisar a la luz de ellas los contenidos culturales regionales y con unas y otras fuentes componer un híbrido que sea capaz de seguir transmitiendo la herencia recibida. Será una herencia renovada, pero que todavía puede identificarse con su pasado."
} 
Os personagens e as coisas surgem nele [em São Bernardo] como meras modalidades do narrador, Paulo Honório, ante cuja personalidade dominadora se amesquinham, frágeis e distantes. Mas Paulo Honório, por sua vez, é modalidade duma força que o transcende e em função da qual vive: o sentimento de propriedade (CANDIDO, 1992, p. 24).

Dentro desta configuração inicial desenvolvida nas primeiras páginas do romance, Paulo Honório apresenta um resumo da sua vida, toda organizada em volta do desejo da posse de São Bernardo. O narrador expressa o desdobramento permanente do discurso narrativo devido à dificuldade de contar a sua vida por escrito: "o meu fito na vida foi apossar-me das terras de São Bernardo, construir esta casa, plantar algodão, plantar mamona, levantar a serraria e o descaroçador, introduzir nestas brenhas a pomicultura e a avicultura, adquirir um rebanho bovino regular" (RAmos, 1994, p. 9). A sua vida está marcada pela pobreza e ignorância no meio rural e pela determinação extrema de superar esta condição. A sua relação conflitiva e desconfiada com o domínio da escrita pode ser retraçada até as suas origens biográficas: não conhece pai nem mãe, só pode se reportar a uma certidão de nascimento, a um documento oficial que evidencia o poder fundamental da escrita e ao mesmo tempo a sua insuficiência. Este não pode lhe dizer quem é, nem a data exata de seu nascimento; radicaliza e institucionaliza a incerteza e precariedade da sua condição de ser.

Para falar com franqueza, o número de anos assim positivo e a data de São Pedro são convencionais: adoto-os porque estão no livro de assentamentos de batizados da freguesia. Possuo a certidão, que menciona padrinhos, mas não menciona pai nem mãe. Provavelmente eles tinham motivo para não desejarem ser conhecidos (RAmos, 1994, p. 10).

Incerteza e precariedade marcam ainda o seu caminho na primeira fase de vida que parece não seguir rumo concreto. A causa de uma paixão superficial por uma mulher mata outro pretendente, uma primeira virada decisiva na biografia de Paulo Honório: na prisão aprende a ler e escrever, consegue o acesso básico ao saber e à instrução (RAMOs, 1994, p. 11-12). Depois inicia um novo projeto de vida, determinado a obter um lugar dentro do poder estabelecido. O Pereira, com quem começa a sua carreira de pequeno capitalista, mais tarde será a sua primeira vítima, vencida com as armas dos negócios financeiros que ele mesmo "ensinara" a Paulo Honório. "De bicho na capação (falando com pouco ensino), esperneei nas unhas do Pereira, que me levou músculo e nervo, aquele malvado. Depois vingueime: hipotecou-me a propriedade e tomei-lhe tudo, deixei-o de tanga. Mas isso foi muito mais tarde" (RAMOS, 1994, p. 12). Ele sabe que para ingressar na ordem do capitalismo precisa de capital, e que na condição de pobre ele não tem como evitar ser explorado para poder adquiri-lo. Outro traço caraterístico dessa ordem capitalista é a luta selvagem de todos contra todos, que Paulo Honório persegue com 
certo prazer, com o sentimento de vingança. Trata-se de um capitalismo rudimentar e abertamente brutal, em um espaço situado entre a cidade e o campo, uma esfera ainda aberta entre o domínio legal de títulos, cartas e contratos e a lei tradicional do mais forte.

O doutor, que ensinou rato a furar almotolia, sacudiu-me a justiça e a religião.

- Que justiça! Não há justiça nem há religião. O que há é que o senhor vai espichar aqui trinta contos e mais os juros de seis meses. Ou paga ou eu mando sangrá-lo devagarinho.

Dr. Sampaio escreveu um bilhete à família e entregou-me no mesmo dia trinta e seis contos e trezentos (RAmos, 1994, p. 13).

Esses atos brutais servem ao objetivo da ascensão social e da acumulação de capital. Quando este chega a uma quantia suficiente, Paulo Honório inicia o plano da sua maior façanha: a posse da fazenda de São Bernardo, propriedade de seu antigo patrão Salustiano Padilha. Outra vez a astúcia financeira e psicológica do pequeno capitalista se mistura com a visão egocêntrica da vingança. Na falta do antigo patrão, já falecido, o alvo é o filho deste, o jovem boêmio Luís Padilha. Paulo Honório aplica as estratégias aprendidas na sua nova "profissão", finge amizade, declara os vários empréstimos como questão de honra. Ao mesmo tempo, se assegura o poder das letras de dívida que Luís Padilha assina e cuja função Paulo Honório maneja com grande habilidade.

Vi essas maluqueiras bastante satisfeito, e quando um dia, de novo quebrado, ele me veio convidar para São João na fazenda, afrouxei mais quinhentos mil réis. Ao ver a letra, fingi desprendimento:

- Para que isso? Entre nós... Formalidades.

Mas guardei o papel (RAmos, 1994, p. 15).

Vão-se acumulando os empréstimos, e Paulo Honório seduz Padilha a se perder entre sonhos de cultivar a fazenda e de entreter-se nas letras, com um insignificante jornal e uma associação literária provinciana. Os dois elementos que regem as ambições de Paulo Honório - o desejo de posse e o desprezo pela cultura letrada - se combinam de forma exemplar no golpe final. Negociando com astúcia e ameaças durante toda uma noite, arranca da sua vítima a fazenda e a consola com recursos limitados para uma nova vida na cidade na direção do Grêmio Literário e Recreativo, cargo patético que evidencia a ambiguidade da cultura letrada com a qual Paulo Honório joga habilmente, mas onde também ele se vai perdendo. Com a aquisição de conhecimentos básicos nesse domínio, e principalmente, com a sua intensificada ambição de propriedade e poder, de prestígio e reconhecimento social, ele já está se envolvendo sem saber nesse terreno alheio e desconhecido.

Transformado em proprietário e fazendeiro, Paulo Honório precisa aprender e respeitar as leis e lógicas do capitalismo moderno. Na divisão do território, porém, 
segue a lei do mais forte. Por falta de recursos - capangas, dinheiro, influência política - não ataca abertamente. O poderoso vizinho Mendonça é assassinado numa emboscada (RAmos, 1994, p. 33). A seguir, arruína Pereira, invade as terras de Fidélis e Gama; só respeita o juiz dr. Magalhães, por ser um potencial aliado político. Avança na modernização da fazenda, manda construir uma estrada de rodagem e ingressa em especulações financeiras de maior lucro.

O momento mais elevado da sua ascensão social é a visita do governador na fazenda. Mas é também o momento em que a conflitante existência da cultura letrada na vida de Paulo Honório chega a um ponto crítico. À sugestão do governador, constrói uma escola para os trabalhadores de São Bernardo e admite assim um elemento fundamental da cultura letrada no coração de sua propriedade e de seu projeto de vida. Adverte Francis Utéza que é o momento em que a sorte de Paulo Honório muda definitivamente.

Na verdade, com exeção da confirmação social que a passagem do representante da autoridade suprema pelas suas terras poderia ter valido ao fazendeiro, quais foram os efeitos concretos dessa visita oficial? Em suma, a construção de uma escola que iria ser a causa dos problemas (UTÉZA, 1991, p. 113-114). ${ }^{2}$

\section{A desconfiança}

Paulo Honório sabe que é um homem solitário desde o seu nascimento, ele agrega em sua volta um grupo de dependentes com certa utilidade, o único círculo social em que se movimenta, e que ele pretende não precisar nem respeitar. A relação contraditória com os seus "amigos assalariados" é atravessada pelo conflito fundamental entre o mundo rural inculto e a cultura letrada. $O$ primeiro exemplo é o próprio Padilha, do qual arranca a fazenda e a quem ele depois instala de novo em São Bernardo, como professor da escola. O próximo exemplo é Seu Ribeiro, que além do mundo letrado representa a transição do nordeste brasileiro para a modernização precária. Com a chegada da estrutura oficial do Estado, o antigo major de um povoado perdeu a sua função de conhecimentos informais e práticos na gerência do local, foi empobrecendo e descendo na estrutura social. Acabou como insignificante funcionário do jornal A Gazeta, em Maceió. Paulo Honório o reconhece como homem honesto e justo e, numa mistura de frio raciocínio e simpatia irracional, o contrata como guarda-livros para a fazenda:

Porém, essa convergência levanta uma questão de fundo ainda mais grave: trata-se de fato de dois homens que ocupavam, cada um de seu jeito, a mesma posição dominante ao centro de seu universo, onde eles

\footnotetext{
2 "En effet, hormis la confirmation sociale que le passage sur ses terres du représentant de l'autorité suprême pouvait avoir valu au fazendeiro, quelles ont été les rétombées concrètes de cette visite officielle ? En tout et pour tout, la mise en place d'une école qui allait devenir la source des problèmes."
} 
captavam as energias da periferia; mas enquanto seu Ribeiro as redistribuia ao seu redor, Paulo Honório as desviava para o seu proveito UTÉZA, 1991, p. 112-113). ${ }^{3}$

Paulo Honório tem consciência de estar situado entre duas épocas e ordens sociais. Ele vem do mundo rural e tradicional, ascendeu e se estabeleceu como dono de terras e gente, mas sem nunca querer ou poder participar de uma sociedade propriamente moderna, que ele desconhece e que o ameaça. Por isso, no destino de Ribeiro ele vê o perigo que ele mesmo corre, de se perder entre os tempos, de ser reduzido outra vez à condição de pobre, impotente e insignificante. Paulo Honório percebe em Ribeiro também o seu oposto, um homem que servia à comunidade em que mandava, uma postura inconcebível para ele, que nunca experimentou comunidade alguma e enxerga o seu entorno como hostil, útil ou manipulável. Se reforça assim a irracionalidade de sua simpatia por Ribeiro, apontando para um terceiro aspecto na relação entre eles: uma saudade inconsciente de Paulo Honório por não poder ser "honesto e justo". Os problemas que surgem entre Ribeiro e Paulo Honório são direcionados para o conflito mais imediato com Madalena.

Quando o narrador conta o momento em que Seu Ribeiro decide abandonar a fazenda, depois da morte de Madalena, outra vez se percebe que ele tem plena consciência da superioridade moral e grandeza humana de seu semelhante e oposto: "assim o excelente Seu Ribeiro, que eu esperava enterrar em S. Bernardo, foi terminar nos cafés ou nos bancos dos jardins a sua velhice e as suas lembranças" (RAmos, 1994. p. 174). Ribeiro vai por causa da morte de Madalena, por causa de tudo que ocorreu em São Bernardo. O matrimônio de Paulo Honório com a jovem professora, que começa numa mistura de raciocínio social e sentimentos encobertos, e que termina na tragédia, está no centro da vida e do romance do narrador. É a própria trama que ele sente a necessidade de relatar por escrito. É também a relação em que se entrecruzam todos os conflitos que regem a vida de Paulo Honório e motivam a sua transformação final em portador do discurso narrativo. O seu ingresso no centro do terreno letrado que teve um papel tão importante na tragédia de Madalena.

Já antes de começar, a relação de Paulo Honório com Madalena está inserida na contradição do fazendeiro rodeado por letrados dependentes. Junto com o projeto de construir uma escola em São Bernardo e encarregar Padilha com o magistério, surgem os primeiros impulsos que levam Paulo Honório a querer casar com a pobre professora de escola municipal, que chegou recentemente a Viçosa. Esta "casualidade é apenas aparente” (LAFETÁ 1994, p. 201), e é verdade que não convence inteiramente a afirmação de Paulo Honório, na abertura do capítulo 11, que inicia a nova fase na sua vida e no romance: "amanheci um dia pensando em casar. Foi

\footnotetext{
3 "Mais cette convergence amène une question de fond autrement plus grave : voici en effet deux hommes qui ont occupé, chacun à leur tour, la même position dominante, au centre de leur univers, où ils captaient les énergies de la périphérie ; mais l'un seu Ribeiro, les rediffusait aussitôt à l'entour, tandis que l'autre, Paulo Honório, les détournait à son seul profit.'
} 
uma ideia que me veio sem que nenhum rabo de saia a provocasse. [...] Não me sentia, pois, inclinado para nenhuma: o que sentia era desejo de preparar um herdeiro para as terras de São Bernardo" (RAmos, 1994, p. 57). Só a última preocupação, a de obter um herdeiro para a propriedade - junto com o casamento como ato de consagração social -, parece seguir estritamente a lógica de Paulo Honório: "a partir do capítulo doze, com o surgimento deste outro motivo - Madalena - tudo se subordina a ele. Todos os motivos temáticos - manobras, negócios, brigas - convergem e encontram sua unidade no novo fito de Paulo Honório, a posse da mulher" (LAFETÁ, 1994, p. 203). ${ }^{4}$ Neste momento, a narração configura um contraponto, um contraste radical entre a brutalidade tradicional de Paulo Honório, enraivecido pelas maquinações de um pequeno letrado urbano, e o seu primeiro passo em direção ao casamento com Madalena, também pequena letrada da cidade. Ele começa a juntar sistematicamente informações sobre Madalena, fica sabendo que ela não somente possui a instrução de uma professora, mas que também escreve para o jornal local.

Azevedo Gondim [...] desmanchou-se em elogios.

- Mulher superior. Só os artigos que publica no Cruzeiro!

Desanimei:

- Ah! Faz artigos!

- Sim, muito instruída. Que negócio tem o senhor com ela?

- Eu sei lá! Tinha um projeto, mas a colaboração no Cruzeiro me esfriou. Julguei que fosse uma criatura sensata (RAmOs, 1994, p. 84).

Mesmo assim Paulo Honório pede a Gondim que prepare o terreno junto à jovem professora, propondo que transfira a funcionária da escola municipal para a de São Bernardo. Logo deixa de lado este pretexto e se abre para Madalena com a pretensão de pedi-la em casamento. Ela hesita, ele tenta convencê-la com argumentos econômicos, mas também Madalena entende imediatamente a dimensão econômica e social da proposta:
- O seu oferecimento é vantajoso para mim, Seu Paulo Honório, mur- murou Madalena. Muito vantajoso. Mas é preciso refletir. De qualquer maneira, estou agradecida ao senhor, ouviu? A verdade é que sou pobre como Job, entende?
- Não fale assim, menina. E a instrução, a sua pessoa, isso não vale nada? Quer que lhe diga? Se chegarmos a acordo, quem faz um negócio supimpa sou eu (RAMOS, 1994, p. 89).

É de estranhar que Paulo Honório utilize o argumento da "instrução como valor". O fazendeiro parece entrar em outra contradição, declarando de forma po-

4 Candido vê neste momento nascer o drama que vai evoluindo no decorrer do romance: "com efeito, o patriarca à busca de herdeiro termina apaixonado, casando por amor; e o amor, em vez de dar a demão final da luta pelos bens, se revela, de início, incompatível com eles” (CANDIDo, 1992, p. 26) 
sitiva justamente aquele aspecto que tanto o desagrada nas pessoas, particularmente em uma mulher que quer para sua esposa. Mas logo relativiza o valor da instrução, incluindo-o num cálculo comercial. Dentro de tais termos econômicos os dois chegam a um acordo, Madalena consente o casamento e não se fala em amor nem em outros sentimentos. Além do declarado "interesse" por Madalena, a irracionalidade das decisões de Paulo Honório a caminho do casamento indica que ainda outra força o motiva. A mistura indefinida de cálculos e sentimentos se funde e confunde de forma expressiva no conceito multifacetado do "desejo" que Paulo Honório sente pela jovem e bonita professora. Luiz Costa Lima detecta até uma "ternura" no rude fazendeiro, analisando como este núcleo de amor é destruído pelo desejo de posse, mas também contribui essencialmente para a intensificação do drama: "Paulo Honório é capaz de ternura e de admirar a mulher culta. Contudo, porque não consegue convertê-la em quantidade precisa, pronta a ser manuseada, troca a sua admiração pela desconfiança. Desconfia daquilo mesmo que nela antes admirava” (Costa LimA, 1969, p. 63).

Esta fusão momentânea do desejo de posse e de um herdeiro, do desejo sentimental e sexual, de cálculo, admiração e ternura, se desfaz após o casamento e a mudança do casal a São Bernardo. Ali ela começa a revelar-se aos olhos de Paulo Honório e a querer participar ativamente na organização da fazenda. Reclama das condições de vida e trabalho dos lavradores e funcionários, critica o baixo ordenado de Seu Ribeiro na presença de outros. Em retrospectiva, Paulo Honório entende que ali se abria o abismo insuperável entre o novo-rico rural e rude e a mulher urbana e letrada, moderna.

Conheci que Madalena era boa em demasia, mas não conheci tudo de uma vez. Ela se revelou pouco a pouco, e nunca se revelou inteiramente. A culpa foi minha, ou antes, a culpa foi desta vida agreste, que me deu uma alma agreste. E, falando assim, compreendo que perco o tempo. Com efeito, se me escapa o retrato moral de minha mulher, para que serve esta narrativa? Para nada, mas sou forçado a escrever (RAmos, 1994, p. 100).

A resposta a esta dúvida fundamental com respeito ao sentido da escrita, é dada pela própria narrativa, declarada inútil. A narração pula repentinamente para o presente do narrador escrevendo em um delírio - desfazendo inclusive a ilusão da escrita do romance pelo personagem literário na situação por ele descrita nos primeiros capítulos. Aparece uma visão de Madalena, os leitores ficam sabendo que o narrado acontecera cinco anos antes, que várias pessoas já morreram, que a casa-grande de São Bernardo está quase vazia e abandonada. Como sombras de um passado não resolvido, cenas da vida com Madalena vão surgindo na mente do narrador paralisado e impossibilitado de continuar escrevendo, mas que mesmo assim continua narrando.

A problemática dos dois mundos, do inculto e do letrado, radicalizada na relação trágica entre Paulo Honório e Madalena, é transposta para o plano da própria 
escrita do romance. A construção de Paulo Honório como personagem e narrador se desarticula momentaneamente, a situação narrativa do texto é suspensa durante o delírio do narrador e o romance explicita por um curto instante a sua própria construção. A problemática do fazendeiro inculto e semiletrado não é somente o narrador, mas inclusive o autor do texto, numa oscilação entre encenação abertamente construída e ilusão imediata. Este momento de desarticulação marca também a passagem da primeira parte do romance para a segunda. A situação narrativa volta ao estado anterior e o narrador Paulo Honório segue com o relato da sua vida, mas uma vez evidenciada a construção e o funcionamento da narrativa tornam-se mais complexos. O próprio ato de narrar e de encenar o papel de narrador, entra em foco e acrescenta ao texto um nível de significação e reflexão. Inclusive obriga a revisar e reler todo o texto anterior à luz desta abertura.

Os desentendimentos entre Paulo Honório e Madalena se intensificam, mesmo contra a intenção declarada do narrador na sua retrospectiva. Este nó indissolúvel é atravessado pela sua relação contraditória com os dependentes cultos que frequentam a casa-grande. Aumentam as situações em que o narrador Paulo Honório explicita a sua sensação de não poder e não querer fazer parte do universo das pessoas ao seu redor.

Puxei uma cadeira e sentei-me longe deles. Era possível que a palestra não me interessasse, mas suspeitei que estivessem falando mal de mim. Provavelmente. Dona Glória sempre com segredinhos ao ouvido de Seu Ribeiro. E Madalena escutando o Padilha. O Padilha, que tinha uma alma baixa, na opinião dela. Para o inferno. Tão bom era um como o outro. Entretidos, animados. Conspiração. Talvez não fosse nada. Mas para quem, como eu, andava com a pulga atrás da orelha! Aborrecia. [...] Levantei-me, encosteime à balaustrada e comecei a encher o cachimbo, voltando-me para fora, que no interior da minha casa tudo era desagradável (RAmOs, 1994, p. 121).

A desconfiança torna-se tão profunda que a própria casa fica "desagradável" para o seu dono e construtor. Esta perturbação em Paulo Honório enquanto personagem e narrador ganha tanta força que até o nascimento de seu filho parece não ter importância. Pior, Paulo Honório deixa cada vez mais claro que não gosta do filho, sem poder ou querer explicar os motivos pela antipatia. Paulo Honório se confunde entre o sentimento de exclusão e de desprezo em relação aos outros, e a desconfiança se transforma em ciúmes. Persegue a esposa, suspeita relações e sentimentos além do permitido entre ela e qualquer homem a sua volta. Briga com ela, depois reorienta seu ódio para Padilha e o despede, tem ataques, não consegue distinguir pesadelos de fatos, sofre de insônia. O final trágico do casamento de Paulo Honório e Madalena é motivado por um papel solto, que ele encontra no chão e identifica como folha de uma carta escrita pela esposa. Para ele é a "prova" pela culpa de Madalena.

Enquanto narrador deixa claro que a sua leitura do texto fragmentário é confusa e orientada pelos ciúmes. Nesta leitura "fracassada" culminam as repetidas 
caraterizações de si mesmo como incapaz de compreender linguagens e discursos cultos. O contraste radical a esta incompreensão última e fatal se constitui pelo ato que consegue transmitir e comunicar a história por ela constituída: pelo próprio ato de narrar e escrever, realizado justamente por aquele que "prova" repetidas vezes a sua inaptidão para lidar com as letras. É mesmo de estranhar - e esta é a contradição central e produtiva - que um leitor tão inapto como Paulo Honório seja o narrador e autor da sua história.

Na igreja de São Bernardo, Paulo Honório tenta forçar Madalena a confessar o nome do destinatário da suposta carta de amor. Madalena há muito entendeu os problemas do marido, sem poder fazer nada para salvar a situação: "O que estragou tudo foi esse ciúme, Paulo" (RAmos, 1994, p. 163). Ela invoca a própria vida, que também começou na pobreza, mas que fez dela uma pessoa frágil e bondosa, se despede e se suicida durante a noite. A carta era dirigida ao próprio Paulo Honório:

Sobre a banca de Madalena estava o envelope de que ela me havia falado. Abri-o. Era uma carta extensa em que se despedia de mim. Lia-a, saltando pedaços e naturalmente compreendendo pela metade, porque topava a cada passo aqueles palavrões que a minha ignorância evita. Faltava uma página: exatamente a que eu trazia na carteira, entre faturas de cimento e orações contra maleitas que a Rosa anos atrás me havia oferecido (RAmos, 1994, p. 169).

É pouco provável que esta primeira leitura da carta de despedida tenha sido tão "ignorante" como Paulo Honório a caracteriza. Logo fica evidente que ele entendeu esta carta mais do que só "pela metade". O ato verdadeiramente exemplar de interpretação errônea e de uma comunicação impedida foi a leitura da folha solta como "prova de infidelidade". Para a sua última mensagem, Madalena escolheu o meio de comunicação menos apropriado a Paulo Honório; ao mesmo tempo recorreu à única maneira que garantia que seu marido ciumento e desconfiado entendesse o que ela tinha que dizer. Pelo acaso da folha solta encontrada, que precipitou os acontecimentos, se desdobra o círculo vicioso da incomunicação entre os esposos, causando uma última briga que parece levar Madalena à morte. Mas a carta completa, intencionada para a leitura posterior à sua morte, obriga Paulo Honório a entender que a sua culpa pelo suicídio dela não se situa na última noite, nem em outro momento específico. $O$ único momento de verdadeira comunicação só poderia acontecer depois da tragédia, e o efeito desse processo é a transformação de Paulo Honório em narrador de sua vida e de sua culpa.

\section{A escrita}

Todos abandonam São Bernardo: Dona Glória, Ribeiro, Padilha, o padre Silvestre. O fazendeiro permanece solitário na sua propriedade, com o fracasso de sua vida. A narração se realiza sob o signo do final, quando o protagonista perdeu as pessoas ao seu redor - momento a partir do qual, segundo Walter Benjamin (1999, 
p. 402), um romance constitui o seu significado. O processo de autorreflexão, iniciado pela morte e carta de Madalena, que por sua vez é a instauração e o motor da escrita do romance, se explicita neste momento em que o tempo narrado e o tempo da narração se vão aproximando.

Faz dois anos que Madalena morreu, dois anos difíceis. E quando os amigos deixaram de vir discutir política, isto se tornou insuportável. Foi aí que me surgiu a ideia esquisita de, com o auxílio de pessoas mais entendidas que eu, compor esta história (RAmos, 1994, p. 183).

É de notar que neste momento admite até que lhe fazem falta os intelectuais e suas conversas sobre política ou assuntos culturais. Vislumbra-se o círculo vicioso - mas não completamente fechado - dos raciocínios de Paulo Honório, que por um sentimento de falta concebe o projeto de escrita "coletiva", para depois rejeitar esta ajuda pelos mesmos motivos que antes nutriam o seu desprezo e desconfiança. De uma justificativa ainda "externa" e superficial, alegando que na vida e no trato com Madalena ele não tinha como ser e atuar de forma diferente, passa imediatamente para uma compreensão dolorosa e profunda de sua vida.

Madalena entrou aqui cheia de bons sentimentos e bons propósitos. Os sentimentos e os propósitos esbarraram com a minha brutalidade e o meu egoísmo. Creio que nem sempre fui egoísta e brutal. A profissão é que me deu qualidades tão ruins. E a desconfiança terrível que me aponta inimigos em toda a parte! A desconfiança é também consequência da profissão (RAMOs, 1994, p. 190).

Esta forma de ser e de ver o mundo não pode se transformar completamente. A resolução de narrar a vida por escrito é um passo radical, difícil e perigoso para Paulo Honório, representa um ato de coragem. Mas ao iniciar a sua realização, volta a aplicar os modelos acostumados de organizar o mundo: "antes de iniciar este livro, imaginei construí-lo pela divisão do trabalho" (RAMOs, 1994, p. 5). A primeira tentativa é concebida como o gerenciamento de uma fazenda e fracassa inevitavelmente. Este início do romance põe em relevo a questão fundamental da linguagem literária. O conflito que se apresenta a Paulo Honório, que não vê a sua história representada adequadamente nas páginas rebuscadas de Gondim, transpõe para o plano intra-literário a discussão que o escritor Graciliano Ramos, no âmbito extraliterário, mantinha com as correntes de seu tempo.

Quinze dias depois do nosso primeiro encontro, o redator do Cruzeiro apresentou-me dois capítulos datilografados, tão cheios de besteiras que me zanguei:

- Vá para o inferno, Gondim. Você acanalhou o troço. Está pernóstico, está safado, está idiota. Há lá ninguém que fale dessa forma! [...]

- Foi assim que sempre se fez. A literatura é a literatura, Seu Paulo. 
A gente discute, briga, trata de negócios naturalmente, mas arranjar palavras com tinta é outra coisa. Se eu fosse escrever como falo, ninguém me lia (RAmos, 1994, p. 7).

Esses "dois capítulos perdidos" da primeira tentativa representam a lógica interna tanto da construção do romance quanto do projeto de Paulo Honório enquanto personagem e narrador, função destacada por Lafetá: "o caso é que não o foram. Sua figura dominadora e ativa está criada. Fomos já introduzidos em seu mundo - um mundo que, em última análise, se reduz à sua voz áspera, ao seu comando, à sua maneira de enfrentar os obstáculos e vencê-los. Um mundo que se curva à sua vontade" (LAFETÁ, 1994, p. 195). A primeira concepção de realização do projeto de contar a própria vida segue exclusivamente a lógica da ascensão a fazendeiro: "Paulo Honório, ao começar o seu livro, repete mecânico o processo em que se especializara: o da divisão de trabalho em que reservava para si o melhor quinhão" (Costa LimA, 1969, p.58). Assim, fica patente a íntima relação entre o domínio de terras e seres humanos e o domínio da escrita e como entram em conflito no espaço de vida de Paulo Honório: "o narrador apresenta-se, de início, como senhor do relato, a exercer sobre ele domínio tão absoluto como sobre a fazenda e os seus habitantes. Os poderes do Paulo Honório - escritor são iguais aos do Paulo Honório-fazendeiro" (Cristóvão, 1986, p. 53).

A escrita não pode ser produzida e administrada como a posse ou gerência da fazenda. Nas mãos de Paulo Honório, entretanto, estes dois atos e domínios evidenciam os seus traços comuns. Ao iniciar a narrativa de sua vida, ele transpõe o seu poder de proprietário ao poder do dono da escrita. Não reproduz exatamente a posição do letrado preso na contradição "externa" de escrever dentro de um meio iletrado. Também não cabe bem na contradição "letrada" de depender dos poderosos no exercício de sua profissão. Contudo, o ato de Paulo Honório de narrar a sua vida em forma de livro aponta para a problemática que, para Rama, é um traço decisivo da cultura letrada latino-americana:

O paradoxo de que seus membros foram os únicos praticantes das letras em um meio privado da cultura letrada, os dons da escritura em uma sociedade analfabeta que procederam em sacralizar dentro de uma gramatologia constituinte da cultura europeia (RAMA, 2000, p. 33).

Este conflito é representado como anacronismo e caricatura nos letrados dependentes em volta da fazenda, mantidos por Paulo Honório como professores, guarda-livros, agentes jurídicos e jornalistas, reproduzindo o modelo tradicional de intelectual-servidor, que está sendo substituído por novos modelos - por exemplo, o intelectual-funcionário público, como o próprio Graciliano Ramos - no processo de modernização que Paulo Honório incorpora de forma tão ambígua. Os "donos" das letras em São Bernardo já não são também os donos do poder, formam um emergente proletário letrado, dependente dos antigos e novos poderosos. 
Ao contrário desse modelo, Paulo Honório experimenta a contradição "interna" da própria cultura letrada, entrelaçada com a esfera do poder, a serviço de sua legitimação e atuando à base desse mesmo poder legitimado. Ele incorpora tão agudamente este conflito da fusão dos dois domínios da posse e da instrução, porque não nasceu nem rico nem letrado, tendo que percorrer todo o trajeto na direção contrária para chegar onde se encontra enquanto personagem e narrador. Este processo se complica com a transição paralela de Paulo Honório entre a ordem tradicional do poder latifundiário e a ordem moderna do poder capitalista:

A crise moral e ética do protagonista impõe assim certo impasse ao narrador, tornando-se crise de narrar, pois ao mesmo tempo em que narra para revelar seu reconhecimento das falas reprimidas do outro, impõe-se autoritariamente como a única fala capaz de produzir sentido para sua vida e a dos outros, ainda que esse sentido seja o da perda de sentido (RAmOS, 1994, p. 51).

Este cruzamento de conflitos leva os leitores até os fundamentos da ordem de uma cultura da escrita e das letras. Representar adequadamente a voz e fala do outro dentro do registro altamente regulamentado e codificado da escrita culta literária - é um dos conflitos centrais que Rama determina na literatura latinoamericana. Não há como escapar da contradição implícita no gesto de reproduzir dentro da cultura letrada estas vozes orais e populares. É inevitável ingressar na ordem letrada para poder influenciar e transformá-la; a transformação da "cidade letrada" só é possível a partir de seu interior, através do discurso letrado.

Toda tentativa de rebater, desafiar ou superar a imposição da escrita passa, obrigatoriamente, por ela mesma. Poderia-se dizer que a escrita acaba absorvendo toda a liberdade humana, porque só em seu campo se dá a batalha de novos setores que disputam posições de poder (RAMA, 2000, p. 52). ${ }^{5}$

Esta contradição fundamental se desdobra em São Bernardo; é posta em cena na busca do personagem-narrador Paulo Honório por uma forma de narrar a sua vida por escrito, e a partir da construção do narrador e da situação narrativa ela rege a constituição do próprio romance. Ele desrespeita não somente as leis internas da literatura, ataca o próprio estatuto social desta e se baseia na sua autoridade de rico fazendeiro para mudar a configuração interna da "cidade letrada". Ao mesmo tempo, desconhecendo aparentemente as leis mais básicas do literário, se revela como astuto dominador das regras e regularidades internas do discurso narrativo. Narrando da forma por ele exigida o exato momento em que formula esta crítica à literatura tradicional, ele subverte a hierarquia e se instaura como instância narrativa. A partir deste momento, todas as restrições formuladas ao seu domínio da

\footnotetext{
5 "Todo intento de rebatir, desafiar o vencer la imposición de la escritura, pasa obligatoriamente por ella. Podría decirse que la escritura concluye absorbiendo toda la libertad humana, porque sólo en su campo se tiende la batalla de nuevos sectores que disputan posiciones de poder."
} 
escrita são regidas paralelamente pela crítica do modelo letrado vigente e pela estratégia legitimadora da própria palavra.

Continuemos. Tenciono contar a minha história. Difícil. Talvez deixe de mencionar particularidades úteis, que me pareçam acessórias e dispensáveis. Também pode ser que, habituado a tratar com matutos, não confie suficientemente na compreensão dos leitores e repita passagens insignificantes. De resto isto vai arranjado sem nenhuma ordem, como se vê. Não importa. Na opinião dos caboclos que me servem, todo o caminho dá na venda (RAmos, 1994, p. 8).

Para Candido, a escrita de Paulo Honório-narrador é regida pela mesma lógica de posse e economia que a vida a ser narrada: "até quando escreve, a sua estética é a da poupança" (CANDIDO, 1992, p. 26). Enquanto personagem criada pelo discurso literário, " $[\mathrm{e}] \mathrm{m}$ Paulo Honório, o sentimento de propriedade, mais do que simples instinto de posse, é uma disposição total do espírito, uma atitude geral diante das coisas" (CANDIDO, 1992, p. 28). Ele se aventura em um território desconhecido, com a necessidade de adquirir e desenvolver novas capacidades, mas grande parte de suas estratégias narrativas, de seu trato da linguagem e da forma de representação, ainda se rege pelo mesmo desejo de posse que impulsionara a conquista de São Bernardo, confluindo de forma contraditória um discurso narrativo inédito, marcado pela sua forma de ser: "Por meio [do livro] obtém uma visão ordenada das coisas e de si, pois no momento em que se conhece pela narrativa destrói-se enquanto homem de propriedade, mas constrói com o testemunho da sua dor a obra que redime" (CANDIDO, 1992, p. 31).

A escrita de um homem bruto e brutal, que é incapaz de deixar de sê-lo voluntariamente, desenvolve uma brutalidade parecida, uma narrativa que destrói o homem que a cria e um discurso literário de expressividade raramente igualada. Não é possível decidir se esta escrita redime Paulo Honório enquanto personagem ou narrador, ou se para ele não há redenção e resta somente para a obra e a sua atuação social no mundo extraliterário. Esta indecisão funciona como um motor da escrita e do texto literário dela resultante (cf. FAcioli, 1993, p. 56). Paulo Honório se transforma de analfabeto em letrado, de pobre em dono de fazenda, e acaba assumindo a contradição - só que sob signos invertidos - que antes lhe causara tanto desconforto, desconfiança e desprezo. Por esta dupla negatividade da sua posição enquanto narrador de si, Paulo Honório poderia até se destacar como o mais honesto dos letrados, presos na contradição entre a palavra escrita e o poder.

\section{São Bernardo: a casa letrada}

A partir da reflexão histórica sobre a função das cidades como pontos de apoio para a colonização da América e como centros de controle e difusão da cultura "civilizadora" (cf. ROMERo, 2004), Rama desenvolve o modelo da "cidade letrada" como paradigma cultural, que transmite os impulsos externos de modernização 
para as respectivas regiões do interior. A "cidade letrada" constitui uma área central, destacada e isolada do restante espaço urbano, situada na proximidade imediata do poder político e econômico; mas também possui uma dimensão semântica e simbólica enquanto modelo cultural vigente na formação da América Latina (RAMA, 2000, p. 24-25).

O ordenamento espacial do modelo semântico e simbólico da "cidade letrada" pode ser aproveitado como ferramenta analítica aplicável também a espaços não propriamente urbanos, porque os seus traços decisivos se encontram na formação sociocultural de áreas marcadas pelas grandes propriedades rurais, como o nordeste brasileiro. Ali, a fazenda funciona como miniatura do modelo urbano colonial, constituída pelo seu centro espacial e simbólico que é a casa-grande, como analisada por Gilberto Freyre (2002), marcada pela oposição fundamental ao modelo letrado e urbano. Cidade colonial e casa-grande não são espaços idênticos nem análogos, entretanto são modelos políticos, econômicos e culturais que convergem nas funções de controle e modernização, o que possibilita apreender as superposições e interpenetrações dessas duas figuras de reflexão.

No romance de Graciliano Ramos, esta superposição adquire uma forma particular. Como Paulo Honório, a configuração econômica e cultural de São Bernardo se situa entre as funções da fazenda tradicional e do espaço urbano na formação histórica do Brasil: "A casa-grande, completada pela senzala, representa todo um sistema econômico, social, político" (Freyre, 2002, p. 131). Paulo Honório já não é um fazendeiro tradicional, muito menos a partir do momento em que assume o papel de narrador da própria vida. Contudo, também não é um fazendeiro moderno, a inversão encarnada por ele serve para focalizar com particular agudeza os conflitos das ordens nas quais ele tanto deseja "ingressar". A sua vida começa na plebe rural, como dependente de uma fazenda, depois se urbaniza justamente na prisão - onde aprende as primeiras letras - e durante o período em que vai aperfeiçoando a sua estratégia de sobrevivência como pequeno capitalista. Esta passagem rápida, mas decisiva pelo mundo urbano culmina com a aquisição de uma casa em Viçosa. Paulo Honório nem considera permanecer na cidade e administrar desde ali a sua fazenda. No passo definitivo para a posse de São Bernardo inclui sem hesitação a casa urbana na quitação das dívidas de Padilha, trocando-a pela casa-grande da fazenda. Esta tem um valor simbólico, uma vez que, estabelecido como dono de São Bernardo e controlados os vizinhos e inimigos, ele manda reconstruir a casa:

Concluiu-se a construção da casa nova. Julgo que não preciso descrevêla. As partes principais apareceram ou aparecerão; o resto é dispensável e apenas pode interessar aos arquitetos, homens que provavelmente não lerão isto. Ficou tudo confortável e bonito. Naturalmente deixei de dormir em rede. Comprei móveis e diversos objetos que entrei a utilizar com receio, outros que ainda hoje não utilizo, porque não sei para que servem (RAMOs, 1994, p. 38). 
A sua recusa em descrever os detalhes da nova casa implica que não seria necessário descrevê-la por que não sai do modelo tradicional de casa-grande nordestina; ao mesmo tempo, a omissão obedece ao estilo de Paulo Honório-narrador, desatento para o acessório, averso ao pitoresco. Ainda outro significado pode ser detectado neste trecho: a nova casa-grande, apesar de ser construída e equipada dentro dos padrões tradicionais, representa um espaço alheio e desconhecido para ele, um modelo moderno suspeito. Ao iniciar-se o discurso narrativo, se entrelaçam o espaço simbólico da casa-grande de São Bernardo e a mise-en-scène do ato da escrita. Paulo Honório, no final de sua vida que está começando a narrar, sozinho na sala, abandonado pelas pessoas que ele ordenara ao seu redor, dá início ao seu manuscrito de relato autobiográfico que é idêntico ao livro nas mãos do leitor. Essa casa-grande, na leitura de Friedrich Frosch, é o centro inicial onde o romance começa com o relato de sua própria gênese, da primeira tentativa fracassada de sua escrita: "o elemento originalmente espacial é o próprio livro: aquele que está frente ao leitor, o produto acabado, mas também aquele 'livro do desejo', cuja gênese penosa se pode apreender no ato de narrar" (Frosch, 1995, p. 143). Em nota de rodapé visualiza o ordenamento espacial da cena inicial:

O primeiro capítulo tem como centro um edifício com varanda. Ao redor dele estão ordenados [...] as localidades adequadas: estalagens e pastos, floresta e uma serraria; uma represa de tijolos; uma capela. Implicitamente, tudo isto sublinha a importância e amplidão da propriedade desse narrador ainda anônimo, que pretende mandar escrever a sua biografia pelos outros, para depois assinar com o seu nome no título (FrOsCH, 1995, p. 143).

Os dois projetos de propriedade e escrita de São Bernardo se fundem e fracassam juntos com a morte de Madalena, para serem recapitulados no ato da escrita: "É este o elemento que constitui o eixo de orientação do romance. Por ele, Paulo Honório 'seleciona' da vida e do mundo os seus aspectos meramente quantitativos ou reduzíveis à quantidade" (Costa LimA, 1969, p. 53). Instalado na sua fazenda, primeiro mandando em coisas, animais e gente, e depois ordenando os significados de sua vida através da escrita, dentro da qual segue a mesma vontade de mando, Paulo Honório incorpora a "cidade amuralhada" da cultura letrada dentro de seu contexto cultural da "cidade real". Esta imagem é, inevitavelmente, ambígua. Paulo Honório engloba este domínio moderno da cultura letrada, ao mesmo tempo em que é o representante mais radical do desprezo e da desconfiança com respeito a ela. Esta contradição se intensifica no ato de escrever realizado, afinal, sozinho, como Paulo Honório narrador do romance. Da mesma forma, outra vez de modo contraditório, Paulo Honório representa a cultura rural do interior, oposta à cultura urbana do litoral e da capital, ao mesmo tempo em que é um expoente exemplar das forças modernizadoras do regime latifundiário na primeira metade do século XX brasileiro (cf. LAFETÁ, 1994, p. 205). 
Um motivo pela força destrutiva desse papel intermediário ou transitório de Paulo Honório se percebe no conflito por ele vivido no espaço vazio entre as duas ordens econômico-sociais. O espaço dentro do qual o protagonista vai se perdendo entre fazendeiro, proprietário e ser humano, na desconfiança que leva à destruição das pessoas em sua volta e à solidão onde acabará abandonado pelos restantes (FACIOLI, 1993, p. 55). Uma chave para esta compreensão é fornecida por Carpeaux:

A sombra sobre o mundo de Graciliano Ramos não é a sombra da árvore da salvação, mas a do edifício da nossa civilização artificial - cultura e analfabetismo letrados, sociedade, cidade, Estado, todas as autoridades temporais e espirituais, que ele convida ironicamente - no começo de São Bernardo - a colaborar na sua obra de destruição (CARPEAUX, 1977, p.32).

Mais uma vez o episódio da primeira tentativa de escrita em divisão de trabalho adquire outra dimensão significativa, como maneira improdutiva e estarrecida de enxergar e representar a realidade cultural. O processo de escrita de Paulo Honório, com toda a encenação de suas dificuldades e imperfeições, está altamente refletido, como mostra o trecho que segue ao episódio em que Paulo Honório relata o primeiro encontro com dona Glória no trem de Maceió a Viçosa.

Essa conversa, é claro, não saiu de cabo a rabo como está no papel. Houve suspensões, repetições, mal-entendidos, incongruências, naturais quando a gente fala sem pensar que aquilo vai ser lido. Reproduzo o que julgo interessante. Suprimi diversas passagens, modifiquei outras. [...] É o processo que adoto: extraio dos acontecimentos algumas parcelas; o resto é bagaço (RAmos, 1994, p. 77).

Estas reflexões sobre a escrita, encenadas dentro do discurso narrativo, levam a outras, mais abertamente de caráter metaliterário. Sobre a falta de descrições paisagistas e os mandamentos da estruturação da narrativa, sobre o início de um novo capítulo que supostamente nem deveria figurar como capítulo independente. Comentários que não por acaso coincidem com o relato do primeiro encontro pessoal entre Paulo Honório e Madalena na estação de Viçosa. Uma vez familiarizado com a construção desdobrada da voz narrativa e as camadas de sua escrita, as considerações iniciais do romance evidenciam ainda mais que ali o texto reflete a sua própria construção. Na metalepse do narrador que relê o que acaba de escrever, ocorre a volta que liga o problema da escrita de Paulo Honório com o da escrita em geral, simbolizado na superioridade de Madalena: "Casimiro Lopes acocorase num canto. Volto a sentar-me, releio estes períodos chinfrins. Ora vejam. Se eu possuísse metade da instrução de Madalena, encoivarava isto brincando. Reconheço finalmente que aquela papelada tinha préstimo" (RAmos, 1994, p. 9). Só a partir do final do romance se acede ao significado desta afirmação, a importância da "instrução de Madalena", a referida "papelada" e o problema central que reside no "préstimo" ou não dela. 
O recurso literário se desmascara a si mesmo, a escrita pretensamente tosca e desajeitada de Paulo Honório-narrador sabe que ela mesma constitui o discurso narrativo: "as pessoas que me lerem terão, pois, a bondade de traduzir isto em linguagem literária, se quiserem. Se não quiserem, pouco se perde. Não pretendo bancar escritor. É tarde para mudar de profissão" (RAmos, 1994, p. 9). A ordem dada ao leitor, de "traduzi-lo" para a "linguagem literária", evidencia um manejo hábil com os recursos narrativos disponíveis, e aproximam as caraterísticas da voz narrativa ao exercício do poder, o domínio do fazendeiro que ele não esconde ser: "com um estremecimento, largo essa felicidade que não é minha e encontrome aqui em São Bernardo, escrevendo. As janelas estão fechadas. Meia-noite. Nenhum rumor na casa deserta" (RAmos, 1994, p. 188). Aqui a imagem criada pela voz narrativa chega à simultaneidade com a imagem inicial do romance - a qual evidenciou a construção da sua voz portadora. No nível da trama, o romance faz coincidir o tempo narrado com o tempo da narração; no nível metaliterário, a imagem inicial se repete e se integra em si mesma. $O$ texto, a voz e a casa se contêm mutuamente, formando o ponto onde a construção do romance se amarra.

Dois movimentos o integram [o romance]: um, a violência do protagonista contra homens e coisas; outro, a violência contra ele próprio. Da primeira resulta São Bernardo-fazenda, que se incorpora ao seu próprio ser, como atributo penosamente elaborado; da segunda, resulta São Bernardo-livro-de-recordações, que assinala a desintegração da sua pujança. De ambos, nasce a derrota, o traçado da incapacidade afetiva (CANDIDO, 1992, p. 29-30).

A partir dali o texto funciona como epílogo metaliterário. O narrador começa e termina sentado sozinho na casa-grande; conta a sua vida e explicita o seu modo de narrar; a narração apresenta a constituição do narrador. As páginas finais passam ao monólogo interior do narrador em tempo presente, resumindo a sua situação depois de ter contado, de ter escrito o livro que está chegando ao fim. É nesta superposição dos planos simbólicos e significativos da totalidade do romance, de seus motivos e a sua representação, que a casa-grande de São Bernardo se converte em "casa letrada", uma miniatura da "cidade letrada" onde se condensam e radicalizam os conflitos entre a ordem culta e o mundo rural, no contexto do nordeste brasileiro.

\section{Referências}

Benjamin, Walter. Illuminationen. Ausgewählte Schriften 1, Frankfurt am Main: Suhrkamp, 1999.

CAndido, Antonio. Ficção e confissão. Ensaios sobre Graciliano Ramos. Rio de Janeiro: Editora 34, 1992.

CAndido, Antonio. Formação da literatura brasileira. (Momentos decisivos). Belo Horizonte, São Paulo: Ed. Itatiaia / Martins, 2000. 
Carpeaux, Otto Maria. "Visão de Graciliano Ramos". In: Brayner, Sônia (org.): Graciliano Ramos. Rio de Janeiro, Brasília: Civilização Brasileira, Instituto Nacional do Livro, 1977, p. 25-33.

Costa Lima, Luiz. Por que literatura. Petrópolis: Vozes, 1969.

CRISTÓvão, Fernando. Graciliano Ramos: estrutura e valores de um modo de narrar. Rio de Janeiro: José Olympio, 1986.

FACIOLI, Valentim. "Dettera: ilusão e verdade - Sobre a (im)propriedade em alguns narradores de Graciliano Ramos”. In: Revista do Instituto de Estudos Brasileiros, São Paulo, n. 35, p 43-68, 1993.

Freyre, Gilberto. "Casa-grande \& senzala. Formação da família brasileira sob o regime da economia patriarcal”. In: SANTiAgo, Silviano (org.): Intérpretes do Brasil. Rio de Janeiro: Nova Aguilar, vol. 2, 2002, p. 121-646.

Frosch, Friedrich: Die Fährnis des Raumes. Erinnern und Wahrnehmung bei Graciliano Ramos. Viena: WUV Universitätsverlag, 1995.

LAFETÁ, João Luiz. "O mundo à revelia". In: Ramos, Graciliano: São Bernardo. 59a. ed. Rio de Janeiro: Record, 1994, p. 192-217.

RAmA, Ángel. La ciudad letrada. za ed. Hanover, NH: Ediciones del Norte, 2000.

Rama, Ángel. Transculturación narrativa en América Latina. 4a ed. México: Siglo XXI, 2004.

Ramos, Graciliano. São Bernardo. 59a ed. Rio de Janeiro: Record, 1994.

Romero, José Luis. Latinoamérica. Las ciudades y las ideas. 2a ed. Buenos Aires: Siglo XXI Argentina, 2004.

Rosenfeld, Anatol. "Graciliano Ramos como poeta da seca". In: Letras e leituras. São Paulo, Campinas: Perspectiva, Edusp, Editora da Unicamp, 1994, p. 137-148.

UtÉzA, Francis. "Graciliano Ramos: la tragédie de São Bernardo". In: Quadrant. Montpellier, n.8, p. 109-134, 1991.

Recebido em 2 de dezembro de 2019.

Aprovado em 8 de abril de 2020. 


\section{Resumo}

A casa letrada: desejo de posse, desconfiança e escrita de Paulo Honório em São Bernardo

\section{Marcel Vejmelka}

Desejo de posse, desconfiança e escrita são os três elementos que representam os aspectos fundamentais tanto do protagonista Paulo Honório quanto da composição do romance São Bernardo, de Graciliano Ramos. Focalizando a importância do contexto da escrita, no seu desdobramento encenado pelo texto do romance enquanto contexto da escrita do narrador e autor, estas três linhas interpretativas se entrelaçam e se combinam de variadas formas, sintetizadas na metáfora analítica da "cidade letrada" (A. Rama). No contexto sociocultural da modernização do Nordeste brasileiro na primeira metade do século XX, a escrita literária enquanto problema e dificuldade, necessidade e possibilidade, representa as dimensões centrais na constituição e construção desse romance.

Palavras-chave: Graciliano Ramos, literatura brasileira, cultura letrada, escrita literária. 